\title{
The Teaching Management Of Higher Vocational Colleges Faces The Problem Of Universality And The Study Of Coping Strategies
}

\author{
Lin Yu \\ Shanghai Xingjian Business College \\ yulin0526@163.com
}

Keywords: Vocational Colleges, Teaching Management, Coping Strategies

\begin{abstract}
China's higher vocational education is faced with the lack of teachers, insufficient funds, the professional class teachers' lack of motivation, student's lack of learning initiative, poor teaching effect. Aiming at specific problems, this article is based on the perspectives of job analysis, career planning, the teaching evaluation system, flexible credit system, platform construction of management in the age of after-student. It attempts to establish the incentive mechanism to promote teachers' teaching ability, scientific research ability, practice ability, innovation ability, improve students' independent learning ability, and fundamentally solve the problem of low teaching efficiency in higher vocational colleges.
\end{abstract}

\section{Background and Significance of the Research}

Education is an important part of education system in China and plays an active role in education. In the face of rapid knowledge update, the transformation of industrial structure, the shortening of product life cycle and enterprise of talent demand is higher and higher, how to train higher vocational students in the fierce competition, the complicated market maintained a sustained competitiveness, has been the higher vocational education should face the most immediate problem. By analysing the present situation of economic management specialty paper, find the problems existing in the professional of administration in higher vocational colleges, put forward new advice, improve the enthusiasm of teachers' innovation and students' adaptability, dynamic capabilities to build a progressive, suitable, system of management professional applied talent cultivation system in higher vocational colleges, as well as the reform of higher vocational education to provide operable paradigm.

\section{The Teaching Status Of The Management Of Education In Higher Vocational Colleges Inadequate teaching team}

Higher vocational education for undergraduate education, insufficient funds, lack of specialized teachers team, according to the related journals of higher vocational education, higher vocational education of specialized course teachers accounted for less than 50\%, economic management professional teachers is lower than $45 \%$, while the ratio of teachers and students, in general, has reached the provisions of the state, but far less than on the ratio of specialized course teachers and students. A teacher in the management major, often appear to be in the same semester on 3 above the door of the specialized course, each course again only on a class, even though many lessons, professional class teacher and it is difficult to meet the requirements of the workload, because professional knowledge update speed, professional class prepares a lesson the teacher constantly throughout the semester, lectures, heavy task, make the teaching effect to sell at a discount greatly, appear "every class will tell, no door was proficient" status, which has seriously hindered the specialized course teachers' professional development. In some professional groups, there is only one person in the group, and every time I arrange the teaching task, it is very hard to arrange the teaching tasks. Due to the low tuition fee, it is difficult to bring in a high level teacher in enterprises or other universities. 


\subsection{The teaching content is old and backward}

Specialized course teachers face the heavy teaching activity, practice research in no time, no opportunity to the enterprise, not timely to update their teaching courseware, teaching case, some obsolete cases in teaching, some teaching data have serious disconnect with reality. In the selection of textbooks, there are also great limitations. In teaching, the teaching materials should be selected for three years, at this level

In teaching materials, there is a shortage of high-quality goods. Some textbooks will find the basic concepts and basic formulas are wrong in teaching. Some of the actual training software has no money to be updated constantly, data is obsolete, the function is backward, even more has been eliminated, but still used in the teaching.

\subsection{Lack of support for professional teachers' research activities}

It is very difficult for ordinary professional teachers in higher vocational colleges to apply for the subject. They think our level is low and we are reluctant to give the project to us. Some of the topics suitable for higher vocational education are too limited. Ordinary professional teachers are hard to get, and some administrative leaders have got the project. They do not do it themselves, or they are assigned to the teacher of the professional course. There is no financial support for the research results of professional teachers, and teachers should publish academic papers on their own expenses. Some academic journals do not accept teachers' articles in higher vocational colleges, and the upstream and downstream of research activities restrict the enthusiasm of teachers in higher vocational colleges.

\subsection{Lack of incentive for full-time teachers}

Well-known national civil service exam every year, new and old students, higher vocational colleges also have jobs hired once every two years, we all have an administrative position, it goes without saying that the two types of jobs there are significant benefits. This is caused by the unfair of performance evaluation, in the daily management process, there are serious "administrative standard" thought, as long as have the administrative position, in pay rise, the title promotion, application for scientific research and social capital value-added aspects will have obvious advantages. Some middle-level cadres of administrative posts have been evaluated on the above title, but they seldom attend classes, and severely squeeze the improvement space of professional teachers. Performance evaluation, and appeared the phenomenon of "insider and outsider", "insiders" everything is easy, "outsiders" everything is difficult, and in this atmosphere, with its good command of professional, is not as good as turned themselves into "insider". Full-time teachers give up the most essential pursuit and pursue his "shortcut".

\subsection{Lack of evaluation criteria for teaching work}

Teaching to the whole team is a lack of communication, each in their own way of specialized course teachers, some teaching content every teacher spoke a lot of time, the students had a tired of emotions, some content again cross blank, each teacher does not speak, not form a cooperative engagement, the professional teaching curriculum is too narrow, without the need to consider some classmates have entrance, some classmate to turn professional. Schools also have no unified standard of teaching evaluation, teacher reference for teaching, every time after the teaching, to teaching contents, test methods, evaluates the results of the evaluation of the student and student, the teaching activity is the obvious result of management, and ignore the process management, there is no communication in the process of teaching and teachers. The educational research group at the same time do not have enough manpower and financial resources for students to set up more elective courses, students have no choice, in the procedural appraisal to the student, the lack of quantitative criteria, subjective evaluation is very strong. In the teaching team's business communication competition, the evaluation standard is very opaque, the fairness is poor, people are not motivated to participate. 


\subsection{Students lack interest and enthusiasm in teaching}

Students in the learning process completely in a passive state, has no right to choose its own professional, without the right to choose courses, has no right to choose their teachers, have no right to arrange their own learning process, it is difficult to arouse the enthusiasm of the students' autonomous learning. Teaching process is actually a soul communication of teachers and students, teaching is not only professional knowledge, but a method, a kind of rigorous doing scholarly research attitude and the character of a loyal to the profession, students have no interest in learning, this is a system problem, our teaching management system, curriculum system, the evaluation index set is not based on real research on planning and design, do not "based on students" management of higher vocational education.

\section{6 "post-student" learning lacks support}

In the next ten weeks of the third semester, students will go to the company for internship, except for graduation and graduation thesis.Lines of communication, other little time to go back to school, some scholars will be at this moment until two years after graduation, students are collectively referred to as the "after" when I was a student, then left school students have not yet fully, also not is really into the workplace, at a time when the students need a management platform, for students looking for work in the process of unease do psychological counseling, self-employment provide guidance for students. In about two years after graduation, students caused by a lack of experience, in cooperation with the company will encounter all sorts of problems, such as the signing of the labor contract, the contract is terminated the, salary, benefits, social problem such as pension, medical insurance, need professional teachers through the platform to provide advice, because the knowledge update speed is quick, the students also need professional teacher update their professional knowledge, in this two and a half years of psychology in the transitional period, almost no school is willing to spend time and energy for the students to build a service platform "after the student age".

\section{The Conception Of The Incentive Mechanism For The Teaching Effectiveness Of Education Management In Higher Vocational Colleges}

Will be higher vocational teaching effectiveness, teachers' teaching and scientific research ability and the relations between and among the learning ability of students by a mathematical formula: the validity of higher vocational education $=$ teachers' teaching and scientific research ability of the students' learning ability $\mathrm{X}$, as long as there is any one factor in the equation is equal to zero, no matter how big, another factor is the effectiveness of the education will be zero. Therefore, to improve the effectiveness of education in higher vocational colleges, it is necessary to raise the enthusiasm of teachers' teaching and research and the initiative of students' autonomous learning. As shown in figure 1 , the internal logic relation of teaching effectiveness can be seen, and the following Suggestions for incentive mechanism will also be carried out around the model.

\subsection{Fair design position, "stable military heart"}

To cultivate excellent students, education must ensure that they have two excellent teams, one is the professional faculty and the other is the team of counselors. In "administrative" management system, the system level of full-time teachers, counselors, administrative management and those logistics personnel to analyze professional jobs, to quantify the workload management, set up fair performance management system, if you don't have a fair performance management system is not possible for you to get a recognition of merit pay, and the workload of pa caused the gap of income inequality, so some full-time teachers transferred to the administration. Higher vocational colleges to redesign a fair system of performance management, make everybody in the material and non-material level can feel is closely relative to pay and reward, contrast between each position can also reveal the fairness and justice. This has stabilized the professional teachers' team to a certain extent and prevented the waste of talents. 


\subsection{Training and development, value-added human capital}

The teacher level determines education level, which determines the quality of talent training. Higher vocational teachers not only have solid theory knowledge but also have a higher level of professional skills, improve teachers' professional quality means mainly to domestic university as a visiting scholar, colleges and universities abroad visiting one's credentials the exercise, to the relevant enterprises. Create high levels of "the double teacher" team, especially some applied university, emphasize the cultivation of practice ability, but don't waste the education theory knowledge, practice is not without theoretical basis of great power. We will enhance the teacher's educational background education and professional knowledge level, so that the teacher has a more open vision and improves the teachers' practical ability through the exercise of the vocational training. In today's rapid development of knowledge, from all walks of life with each passing day, higher vocational teachers must constantly update their knowledge and ability structure, to adapt to the dynamic change of the outside world and students of diverse demand. Schools must provide more opportunities to ensure that teachers' human capital is constantly upgraded to meet teachers' desire to constantly update their knowledge.

\subsection{Focus on career planning}

Due to some unclear orientation of higher vocational colleges, there is no guide correctly for teachers' professional development, the school also often do not attach importance to teachers' professional development, think career planning is a teacher himself. School organization to break the traditional administrative system under the strict hierarchical, highlight the management concept of "service for the teachers", embodies the thought of "people-oriented", to create a harmonious, democracy, equality of the management system, create a respect for talent, reuse talents, cultivating talents and retain talents of campus cultural atmosphere. Set up special organizations, with the help of professional personnel, to provide the resources of the priority, build multiple career development path, to establish a fair and efficiency evaluation mechanism, provide guarantee for teachers' career planning. School offers the support of human, material and financial resources, the realization of self-worth, to ensure the teachers to remove the trouble back at home of the teacher, largely enhance the sense of identity and loyalty on the part of teaching, arouse the enthusiasm of the teachers' hard work.

\subsection{Establish a fair and transparent research incentive mechanism}

Higher vocational teachers' scientific research issue in the industry, is the key to vocational education experience in Singapore believes that "higher vocational school teachers' scientific research ability is the only measure of the value of the school orientation", the development of higher vocational education connotation of Singapore is to improve teachers' scientific research ability, teachers scientific research ability, higher vocational education "work-integrated learning", "production" mode of education cannot be effectively. The professional quality of higher vocational teachers mainly embodies the following four abilities: the ability of teaching, the ability of scientific research, the ability of practice and the ability of innovation. The enhancement of scientific research ability will promote the teaching, practice and innovation ability to a great extent, and also enhance the competitiveness of the school in the industry. As a higher vocational college, it should create a good atmosphere of scientific research, help teachers to overcome difficulties, develop progressive incentives, and enhance the enthusiasm of teachers to participate in scientific research. In view of the problems of education reform, academic exchanges should be carried out within the school scope or within the teaching team to promote the development of scientific research results. In higher vocational colleges should be at the policy level, the teachers' scientific research motivation, to provide research opportunities, hardware support, encourage the teaching team for scientific research, produced a large number of strong scientific research ability of the teaching team.

\subsection{Establish a quantitative teaching evaluation system}

For the evaluation of teaching effect, from different perspectives, in the school's point of view, mainly through the office of the talent training scheme, clear orientation, clear structure and practical ability of student's quality requirements. Timely communicate with professional teachers to revise the 
teaching plan, timely update the teaching quality monitoring basis. Through the teaching system of teaching supervision, the interaction between teachers in class and students, the teaching effect of teachers, and the innovation of teaching methods are discussed in a timely manner. Based on the perspective of teachers' own, be clear what they teach in the position and the specific requirements of professional learning, teaching plan and the basis of cultivation target is to organize teaching, the teaching team, by mutual listening, mutual, mutual learning between teachers, cross discussion to improve the teaching quality. Student's point of view, according to the evaluation criteria of teaching scale, control the teaching process one by one, pay for graduates is the university three years of study to evaluate, courses and teaching help students career whether. From the perspective of society, we will keep track of interns and graduates, timely understand the effect of talent training, monitor existing problems and improve timely.

Design the weight of standard scale, academic and teaching supervision 10\%, students accounted for $10 \%$, enterprises accounted for $20 \%, 10 \%$ own $10 \%$ of teachers, teaching team, because the teaching team is the most understanding of teaching situation, it is the most professional of teacher evaluation, but also take into account the comprehensive teaching evaluation model.

\subsection{Construction of "elastic" credit system}

"Elastic" the establishment of the credit system, students have to choose its own discipline, choose courses, choose teachers and choose the power of the learning process, in the process of learning to increase the weight of the autonomous learning, improve the enthusiasm of active learning, it avoids the unified arrangement, the state of "elective", "course" is the limited set of elective courses, students have no choice, the content of the course and students' interest, no correlation research direction, in order to take enough credits, are forced to learn, have no effect, greatly reduced the effectiveness of teaching. "Flexible credit system" allows students to avoid the situation of passive selection, and have the opportunity and the right to choose courses suitable for their development direction.

\subsection{Designed for students' teaching system}

Professional courses of administration must be suitable for the students' characteristics, can't be a lite version of simple universities and colleges of undergraduate course, practice without engineering practice of administration, equipment of rich content, in order to ensure the quality of teaching, should take the feasible reform measures, as soon as possible with modular teaching plan and curriculum system of basic, crossed, compatibility and applicability, cultivate suitable for higher vocational education level of dynamic capabilities applied talents of resilient .

The system embodies the requirement of the students' basic quality, and embodies the requirement of the basic skills of professional course, core curriculum to highlight the focus of the status, students can according to your own research direction and hobby to choose their own like professional direction. In the whole training system to increase the rights of students' course selection, the elaboration of six modules, there are three modules students can choose from, the enthusiasm of students learning, learning curriculum and students to establish a benign interaction, making the effectiveness of teaching was improved.

\subsection{Build the "post-student" era learning platform}

QQ group, fetion, WeChat, easecredit and class, these are "communication platform" as the development of information technology also is able to progress, build the platform between teachers and students in specialized course, even if the students after graduation, also in the interaction between teachers and students, we can provide professional service for the students on the platform, for example, the cases of labor disputes, labor contract template, interview skills, recruitment, training, examination information, market research questionnaire, etc. If you have questions about trade secrets, you can communicate one-on-one. Lecture on the platform to launch the latest state of the economy, "all the area", "small micro enterprise", "public entrepreneurship, peoples innovation", "the" space ", "create", etc. The development trend of the latest and cutting-edge. Students can learn knowledge on the platform and guide students in the direction of career development. Students can also communicate 
with professional teachers and solve problems together. For students, solve the practical problems in work, for teachers, this research is a practical problem, promote the combination of theory and practice, for the teachers' teaching and scientific research activities provided a practical case, the aim of teaching is learning, we were in the school of classroom education to outspread, make higher vocational education effectiveness and making a big push.

\section{Conclusion}

The improvement of teaching effectiveness of education in higher vocational colleges requires higher vocational colleges to establish a scientific, just and quantifiable evaluation mechanism at the institutional level. Let the students and teachers in the teaching activity guided play to students' learning enthusiasm and mobilize the enthusiasm of teachers' teaching, scientific research, practice and innovation, fundamentally solve the problem of the effectiveness of the higher vocational education.

\section{References}

[1] liu gan yong. Research on human resources development based on dynamic capability theory [J], science and technology and management. 2012. (1) :112-115.

[2] CAI xuemei, wu chuanyan. Reflections on the career planning of teachers in higher vocational colleges [J]. Industry and technology BBS. 2014 (13) :246-247.

[3] song lixia. The enlightenment of Singapore professional education on the cultivation of Chinese teachers' research ability [J]. China adult education 2014 (9):109-110.

[4] wang zhi. Methods and innovation of core competence of students in the management of higher vocational colleges [J]. Heilongjiang high education research 2006. (6) :70-72.

[5] hu seaman. Understanding the current situation of education in higher vocational colleges and deepening the reform of education $[\mathrm{J}]$.

[6] sun yingjun. Innovation: the best choice for the training mode of "engineering characteristics" in the management of professional engineering [J], journal of Shanghai institute of technology (social sciences). 2012 (4) :316-319. 